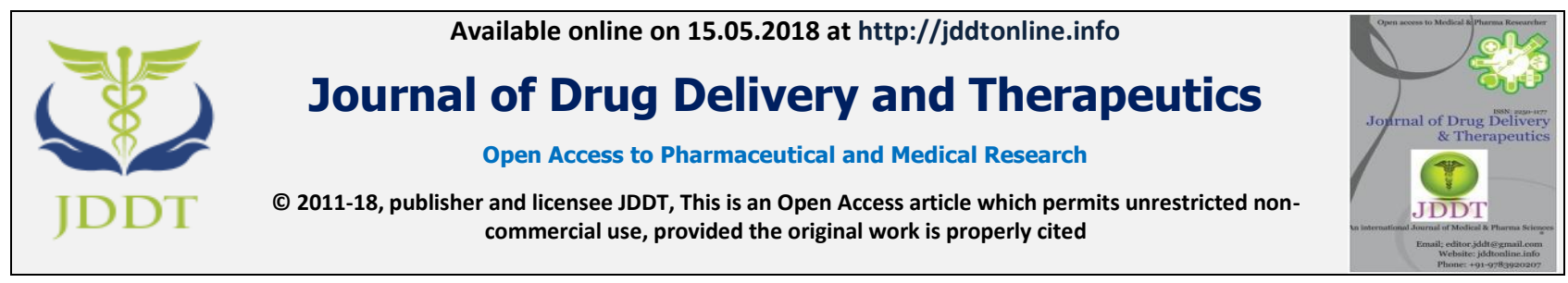

Open $\odot$ Access

Research Article

\title{
SCREENING OF DRUG RELATED PROBLEMS IN HIV PATIENTS RECEIVING ANTI RETROVIRAL THERAPY
}

\author{
C. Gopinath $^{1}$, V. Sravani ${ }^{1}$, Madhan Mohan Rao $^{2}$, D. Girirajasekhar ${ }^{1}$ \\ ${ }^{1}$ Annamacharya College of Pharmacy, New Boyanpalli, Rajampet-516126, Andhra Pradesh, India \\ ${ }^{2}$ Rajeev Gandhi Institute of Medical Sciences, Kadapa-516002, Andhra Pradesh India
}

\begin{abstract}
Aim: The main aim of the study is prospective screening of drug related problems in ART receiving patients at RIMS Kadapa. Objectives: The key objectives of the study include To identify various drug related problems using various domains as per PCNE (Pharmaceutical care network Europe). To identify the most common ART regimen causing DRP. Methodology: A prospective observational study conducted for a period of six months november2015-april 2016. The data was collected by using Patient Data Collection Form, PCNE classification V5.01, Drug interaction form, ADR form. The collected data was analysed for age and gender distribution, distribution of patients based on co morbidities, patients with and without DRPs based on type of ART regimen used, distribution of problems, causes for different problems, interventions suggested for different problems then outcome of interventions were calculated. Results: A total of 125 patients 104 members experienced DRPs with ART regimens, which accounts 63(60.57\%) males and 41(39.42\%) females. Out of 104 patients 59 members experienced DRPs with ZLN regimen. In those patients the main DRPs were adverse drug reactions, drug use problems and drug interactions. The main causes for those problems were Pharmacokinetic problems incl. Ageing/ deterioration in organ function and interactions (C1.4), manifest side effect no other cause (C1.8) as per PCNE scheme V5.01. The various interventions suggested for those problems were Patient (medication) counselling (I2.1), Instructions for use changed to......(I3.4), new drug started(I3.6). the outcomes for suggested interventions were problems( Rashes, muscle pain, vomiting, nausea, headache, cough, abdominal pain.....etc.) totally solved(O1.0) and problems (Neutropenia, anaemia, hyper pigmentation of skin \& nails, ear impairment, severe anaemia, finger paralysis, blurred vision.....etc.) were partially solved(O2.0). Conclusion: Our study concludes adverse drug reactions with ART are high in problems domain as per PCNE, which can be decreased by identifying DRPs in early stages of drug therapy, prescribing other drugs cautiously in HIV patients. Majority of DRPs can be decreased by improving patient-physician relationships and patient-pharmacist relationships. For better outcomes patient counselling can be considered as a better interventional tool which will improve adherence and decrease DRPs in HIV patients.
\end{abstract}

Keywords: Pharmaceutical Care Network Europe, Drug related problems, Anti retro viral therapy

Article Info: Received 21 March, 2018; Review Completed 11 April 2018; Accepted 12 April 2018; Available online 15 May 2018

Cite this article as:

Gopinath C, Sravani V, Rao MM, Girirajasekhar D, Screening of drug related problems in HIV patients receiving anti retroviral therapy, Journal of Drug Delivery and Therapeutics. 2018; 8(3):20-28 DOI: http://dx.doi.org/10.22270/jddt.v8i3.1754

口ifting *Address for Correspondence:

Dr. C. Gopinath, Principal, Annamacharya College of Pharmacy, New Boyanpalli, Rajampet-516126, Andhra Pradesh, India.

\section{INTRODUCTION}

\section{Introduction to DRP's:}

Drugs are a dualistic therapeutic tool. They are intended to cure, prevent or diagnose diseases, signs or symptoms, but the shadow side is that improper use can be the cause of patient morbidity and even mortality. In general, problems related to the use of approved drugs can be summarised with the term "drug-related problems". 1

A Drug-Related Problem is an event or circumstance involving drug therapy that actually or potentially interferes with desired health outcomes. DRPs can be divided into intrinsic and extrinsic toxicity. Intrinsic toxicity is caused by the interaction of the pharmaceutical, chemical and/or pharmacological 
characteristics of the drug itself and the human biosystem. Intrinsic toxicity is synonym for adverse drug reactions. ${ }^{2}$ ADRs can be classified using the WHO adverse reaction terminology. ${ }^{\mathbf{1 , 3}}$ According to this, ADRs are divided into 32 system-organ classes. Extrinsic toxicity refers to the problems caused by the handling of the drug either by the healthcare professional or by the patient. The drug is not used in the proper way a medication error has been made. Medication errors can be divided into five main classes: prescribing, transcription, dispensing, administration (including non-compliance), across settings (errors occurring on the interface between different healthcare settings - for example, between hospital and ambulatory care).

\section{Introduction to PCNE classification of DRP'S:}

$>$ During the working conference of the Pharmaceutical Care Network Europe in January 1999, a classification scheme was constructed for drug related problems (DRPs).

The classification is part of a total set of instruments. The set consists of the classification scheme, reporting forms and cases for training or validation.

$>\quad$ The classification system is validated and adapted regularly.

\section{Different versions of PCNE classification:}

PCNE Classification for Drug related problems $\mathrm{V} 1.2^{4}$; V2.0; V2.04 ; V3.0; V3.01 ${ }^{6}$; V3.02; V4.00 ; V5.01.

PCNE Classification for drug related problems V5.01 ${ }^{8}$

Table 1: The basic classification

\begin{tabular}{|c|c|c|}
\hline & $\begin{array}{l}\text { Code } \\
\text { V5.01 }\end{array}$ & Primary domains \\
\hline \multirow[t]{6}{*}{ Problems } & P1 & $\begin{array}{l}\text { Adverse reaction(s) } \\
\text { Patient suffers from an adverse drug event }\end{array}$ \\
\hline & $\mathrm{P} 2$ & $\begin{array}{l}\text { Drug choice problem } \\
\text { Patient gets or is going to get a wrong(or no drug)drug for his/her disease and/or } \\
\text { condition }\end{array}$ \\
\hline & P3 & $\begin{array}{l}\text { D0sing problem } \\
\text { Patient gets more or less than the amount of drug he/she requires }\end{array}$ \\
\hline & P4 & $\begin{array}{l}\text { Drug use problem } \\
\text { Wrong or no drug taken/administered }\end{array}$ \\
\hline & P5 & $\begin{array}{l}\text { Interactions } \\
\text { There is a manifest or potential drug-drug or drug food interaction }\end{array}$ \\
\hline & P6 & Other \\
\hline \multirow[t]{6}{*}{ Causes } & $\mathrm{C} 1$ & $\begin{array}{l}\text { Drug/dose selection } \\
\text { The cause of the DRP can be related to the selection of the drug and/or dosage schedule }\end{array}$ \\
\hline & $\mathrm{C} 2$ & $\begin{array}{l}\text { Drug use process } \\
\text { The cause of the DRP can be related to the way the patient uses the drug, in spite of } \\
\text { proper dosage instructions(on the label) }\end{array}$ \\
\hline & $\mathrm{C} 3$ & $\begin{array}{l}\text { Information } \\
\text { The cause of the DRP can be related to a lack or misinterpretation of information }\end{array}$ \\
\hline & $\mathrm{C} 4$ & $\begin{array}{l}\text { Patient/psychological } \\
\text { The cause of the DRP can be related to the personality or behaviour of the patient }\end{array}$ \\
\hline & C5 & $\begin{array}{l}\text { (pharmacy)logistics } \\
\text { The cause of the DRP can be related to the logistics of the prescribing or dispensing } \\
\text { mechanism }\end{array}$ \\
\hline & C6 & Other \\
\hline \multirow[t]{5}{*}{ interventions } & 10 & No intervention \\
\hline & 11 & At prescriber level \\
\hline & 12 & At patient(or carer)level \\
\hline & 13 & At drug level \\
\hline & 14 & Other \\
\hline \multirow{4}{*}{$\begin{array}{l}\text { Outcome of } \\
\text { intervention }\end{array}$} & $\mathrm{O} 0$ & Outcome intervention unknown \\
\hline & $\mathrm{O} 1$ & Problem totally solved \\
\hline & $\mathrm{O} 2$ & Problem partially solved \\
\hline & $\mathrm{O} 3$ & Problem not solved \\
\hline
\end{tabular}




\section{Aim}

The main aim of the study is prospective screening of drug related problems in ART receiving patients at RIMS Kadapa.

\section{Objectives of the study}

The key objectives of the study include

* To identify various drug related problems using various domains as per PCNE (Pharmaceutical care network Europe).

* To identify the most common ART regimen causing DRP.

\section{Methodology}

\section{Study design and study period:}

\section{Study design}

It is a prospective observational study.

\section{Study period}

The present study was carried out for a period of six months (November 2015-April 2016)

\section{Study site}

The present study was conducted at Rajiv Gandhi Institute of Medical Sciences (RIMS) government general hospital at the out -patient department, Kadapa.

\section{Source of data:}

The data was collected from patient medication charts, patient medication history interview and laboratory reports.

\section{Inclusion criteria:}

- $\quad$ All the patients of either sex receiving ART.

- $\quad$ All patients with co morbidities.

\section{Exclusion criteria:}

- $\quad$ Pediatrics

- $\quad$ Pregnant women

\section{Method of data collection:}

Data was collection was planned as follows:

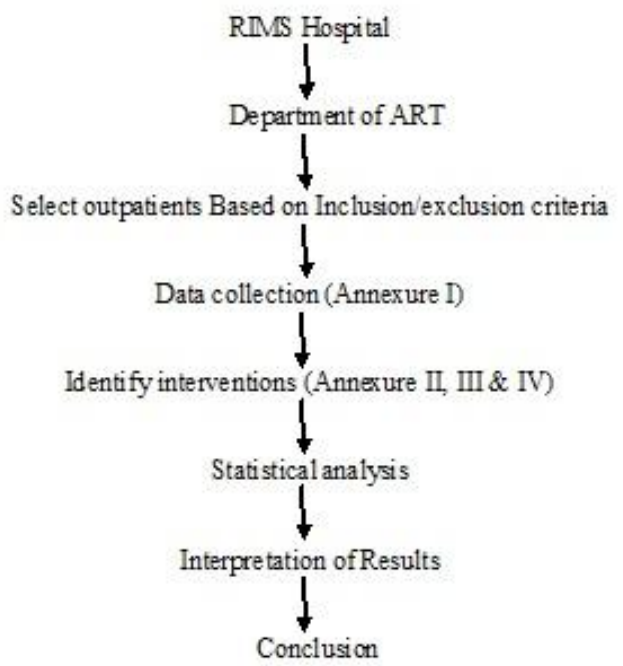

The data collection was done by using the following documents:

- $\quad$ Annexure-1 (Patient Data Collection Form)

- $\quad$ Annexure-2 (PCNE classification V5.01)

- $\quad$ Annexure-3 (Drug interaction form)

All the collected prescriptions were screened for drug-drug interactions using micromedex online and categorized into various types as shown in the annexure.

- $\quad$ Annexure-4 (ADR form)

\section{Statistical analysis:}

$>\quad$ All the data of recruited patients was entered into Microsoft office excel spread sheet and mean was calculated for differentiating the patient's age groups and classifying patient ART regimen.

$>\quad$ Graph pad Prism Soft ware V5.1 was used to plot the graphs regarding age groups and PCNE.

\section{RESULTS}

In order to screen various DRPs in the present study a total of 125 patients treated with different ART regimens were included from the department of ART in RIMS hospital Kadapa for a period of six months from February 2016 to July 2016. Out of 125 patients 104 members experienced DRPs, which accounts $63(60.57 \%)$ males and 41(39.42\%) females.

Distribution of patients based on age group and gender:

All the patients with DRPs were classified in to different age groups based on their gender.

Table 2: Patients with DRPs based on age group and gender:

\begin{tabular}{|l|l|l|l|l|l|}
\hline Age/ Gender & $\mathbf{1 9 - 2 8}$ & $\mathbf{2 9 - 3 8}$ & $\mathbf{3 9 - 4 8}$ & $\mathbf{4 9 - 5 8}$ & $\geq \mathbf{5 9}$ \\
\hline Male & $10(9.61 \%)$ & $23(22.11 \%)$ & $12(11.53 \%)$ & $9.61 \%)$ & $8(7.69 \%)$ \\
Female & $14(13.46 \%)$ & $17(16.34 \%)$ & $5(4.80 \%)$ & $84 \%)$ & $01(0.96 \%)$ \\
\hline Total & $24(23.07 \%)$ & $40(38.45 \%)$ & $17(16.33 \%)$ & $3.45 \%)$ & $9(8.65 \%)$ \\
\hline
\end{tabular}




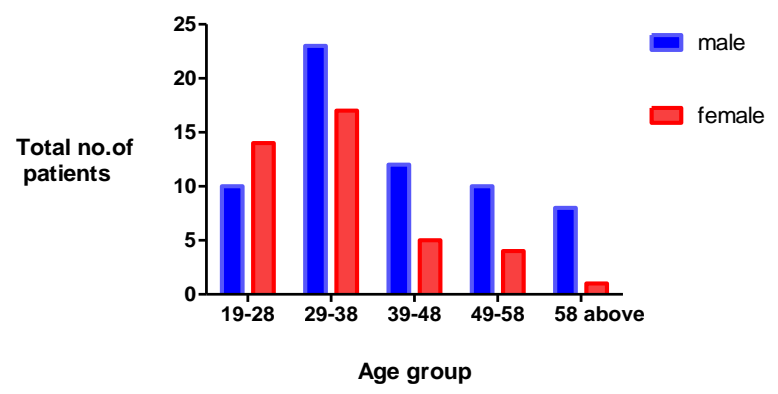

Figure 1: Graph representing patients with DRPs based on age group and gender
Distribution of patients based on co-morbidities:

In the total of 104 cases $77(74.03 \%)$ doesn't have any co morbidities. Tuberculosis (TB) was the most common co morbidity contributed to $27(25.96 \%)$ patients among them $18(66.66 \%)$ are males and $9(33.33 \%)$ are females.

Distribution of patients with and without DRPS based on art regimen used $(\mathrm{N}=125)$ :

In our study all the patients were treated with five different ART regimens. Patients experiencing DRPs during the study period was $104(83.2 \%)$ and patients without experiencing any DRPs during the study period were $21(16.8 \%)$.

Table 3: Distribution of patients with and without DRPs based on ART regimen used

\begin{tabular}{|c|l|c|c|}
\hline S.No & \multicolumn{1}{|c|}{ Therapy used } & $\begin{array}{l}\text { patients with } \\
\text { DRPs (N=104) }\end{array}$ & $\begin{array}{l}\text { patients without } \\
\text { DRPs (N=21) }\end{array}$ \\
\hline 1 & Zidovudine + Lamivudine + Neviraine (ZLN) & $59(56.73 \%)$ & $11(52.38 \%)$ \\
\hline 2 & Tenofovir + Lamivudine + Efavirenz (TLE) & $33(31.73 \%)$ & $5(23.80 \%)$ \\
\hline 3 & Zidovudine + Lamivudine + Efavirenz (ZLE) & $4(3.84 \%)$ & $1(4.76 \%)$ \\
\hline 4 & Tenofovir + Lamivudine+ Atazanavir/ Ritonavir (TL+Ata/Rit) & $6(5.76 \%)$ & $3(14.28 \%)$ \\
\hline 5 & Zidovudine + Lamivudine + Atazanavir/ Ritonavir (ZL+Ata/Rit) & $2(1.92 \%)$ & $1(4.76 \%)$ \\
\hline
\end{tabular}

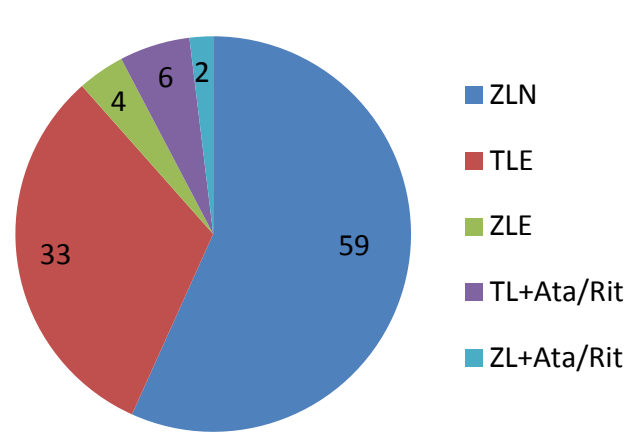

Figure 2: Graph representing the severity of DRPs in different ART regimens
Drug-related problems as per PCNE:

\section{Problems:}

As per PCNE we have found 183 DRPs in 104 patients and the rate of DRP was 1.75 per patient. In the problems domain there are six main domains consisting of $21 \mathrm{sub}$ domains whereas in our study we found only problems in 3 main domains with six sub domains.

The 3 main domains are adverse reactions, drug use problem, interactions. In these domains 123(67.21\%) problems were identified in adverse reactions domain, $48(26.22 \%)$ problems in drug use problem domain and $12(6.55 \%)$ problems in interactions domain.

Table 4: Distribution of problems as per PCNE

\begin{tabular}{|l|l|l|c|}
\hline Primary domain & Code & Detailed classification & No. of problems \\
\hline \multirow{3}{*}{ Adverse reactions } & P1.1 & Side effect suffered (non-allergic) & 87 \\
& P1.2 & Side effect suffered (allergic) & 33 \\
& P1.3 & Toxic effects suffered & 3 \\
\hline Drug use problem & P4.1 & Drug not taken/administered at all & 9 \\
& P4.2 & Wrong drug taken/administered & 12 \\
\hline Interactions & P5.1 & Potential interaction & Total=183 \\
\hline
\end{tabular}




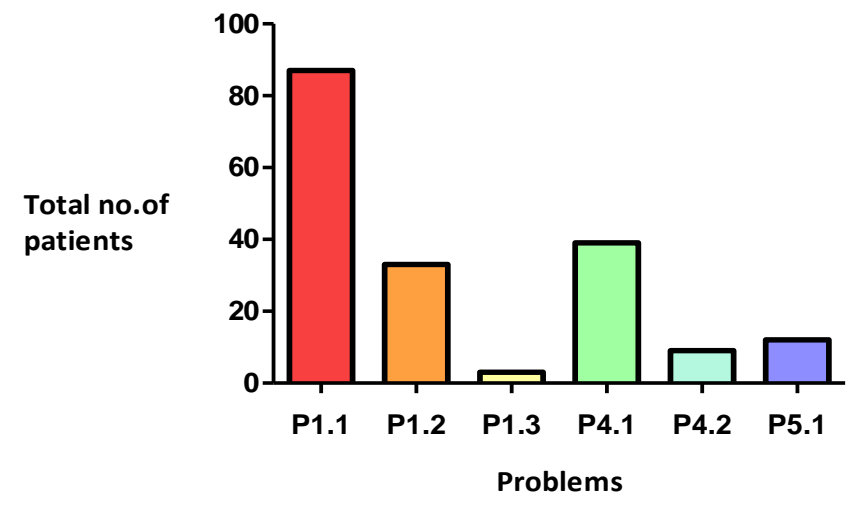

Figure 3: Graph representing problems as per PCNE

Table 5: List of Problems identified in problems domain and sub domains

\begin{tabular}{|c|c|c|c|c|c|c|c|}
\hline \multirow[t]{2}{*}{ S.No } & \multirow{2}{*}{$\begin{array}{l}\text { Primary } \\
\text { domain }\end{array}$} & \multirow[t]{2}{*}{ Code } & \multirow[t]{2}{*}{ Detailed classification } & \multirow[t]{2}{*}{ Problem } & \multicolumn{2}{|c|}{ Gender } & \multirow[t]{2}{*}{ Total } \\
\hline & & & & & Male & Female & \\
\hline \multirow[t]{18}{*}{1} & \multirow{18}{*}{$\begin{array}{l}\text { Adverse } \\
\text { reactions }\end{array}$} & \multirow[t]{14}{*}{ P1.1 } & \multirow{14}{*}{$\begin{array}{l}\text { Side effect suffered (non- } \\
\text { allergic) }\end{array}$} & Anaemia & 13 & 11 & 24 \\
\hline & & & & Muscle pain & 5 & 3 & 8 \\
\hline & & & & Vomiting & 3 & 4 & 7 \\
\hline & & & & Nausea & 4 & 3 & 7 \\
\hline & & & & Headache & 2 & 5 & 7 \\
\hline & & & & Abdominal pain & 2 & 3 & 5 \\
\hline & & & & Neutropenia & 2 & 3 & 5 \\
\hline & & & & Lack of appetite & 4 & 1 & 5 \\
\hline & & & & Lack of sleep & 1 & 1 & 2 \\
\hline & & & & Dreams fatigue & 0 & 1 & 1 \\
\hline & & & & Stomach burning & 1 & 1 & 2 \\
\hline & & & & Diarrhoea & 4 & 2 & 6 \\
\hline & & & & Throat irritation & 2 & 0 & 2 \\
\hline & & & & Blurred vision & 2 & 4 & 6 \\
\hline & & $\mathrm{P} 1.2$ & Side effect suffered (allergic) & Rashes & 21 & 12 & 33 \\
\hline & & \multirow[t]{3}{*}{ P1.3 } & \multirow[t]{3}{*}{ Toxic effects suffered } & Ear impairment & 1 & 0 & 1 \\
\hline & & & & Severe anaemia & 0 & 1 & 1 \\
\hline & & & & Finger paralysis & 1 & 0 & 1 \\
\hline
\end{tabular}

\begin{tabular}{|l|l|l|l|c|c|c|}
\hline S.no & \multirow{2}{*}{$\begin{array}{c}\text { Primary } \\
\text { domain }\end{array}$} & Code & \multicolumn{1}{|c|}{ Detailed classification } & \multicolumn{2}{|c|}{ Gender } & Total \\
\cline { 5 - 7 } & & & Male & female & \\
\hline 2 & $\begin{array}{l}\text { Drug use } \\
\text { problem }\end{array}$ & $\mathrm{P} 4.1$ & Drug not taken/ administered at all & 19 & 20 & 39 \\
\cline { 3 - 7 } & $\mathrm{P} 4.2$ & Wrong drug taken/administered & 4 & 5 & 9 \\
\hline
\end{tabular}

\begin{tabular}{|c|c|c|c|c|c|c|c|}
\hline \multirow{2}{*}{$\begin{array}{l}\text { S.n } \\
\text { o }\end{array}$} & \multirow{2}{*}{$\begin{array}{l}\text { Primary } \\
\text { domain }\end{array}$} & \multirow[t]{2}{*}{ Code } & \multirow{2}{*}{$\begin{array}{c}\text { Detailed } \\
\text { classification }\end{array}$} & \multirow{2}{*}{ Interacting drugs } & \multicolumn{2}{|c|}{ Gender } & \multirow{2}{*}{$\begin{array}{c}\text { Tota } \\
1\end{array}$} \\
\hline & & & & & Male & Female & \\
\hline \multirow{4}{*}{3} & \multirow{4}{*}{ Interactions } & \multirow{4}{*}{ P5.1 } & \multirow{4}{*}{$\begin{array}{l}\text { Potential } \\
\text { interaction }\end{array}$} & Pantoprazole + rifampicin & 1 & 0 & 1 \\
\hline & & & & Pantoprazole + atazanavir & 0 & 1 & 1 \\
\hline & & & & $\begin{array}{l}\text { IFA(iron folic acid)+IER (isoniazid+ } \\
\text { ethambutol+ rifampicin) }\end{array}$ & 4 & 2 & 6 \\
\hline & & & & $\begin{array}{l}\text { IFA(iron folic acid)+PER } \\
\text { (pyranzinamide+ ethambutol+ rifampicin) }\end{array}$ & 1 & 1 & 2 \\
\hline & & & & $\begin{array}{l}\text { IFA+ IER (isoniazid+ ethambutol+ } \\
\text { rifampicin) }\end{array}$ & 1 & 1 & 2 \\
\hline
\end{tabular}




\section{Causes:}

As per PCNE we have found 183 causes for 183 DRPs in 104 patients. In the causes domain there are six main domains consisting of 34 sub domains whereas in our study we found only problems in 4 main domains with ten sub domains.
The 4 main domains are Drug/dose selection, drug use process, information, patient/psychological. In these domains $124(67.75 \%)$ causes were identified in Drug/dose selection, 17(9.28\%) causes in drug use process domain, $2(1.09 \%)$ causes in information domain and $40(21.85 \%)$ causes in patient/psychological domain.

Table 6: List of causes for problems identified as per PCNE

\begin{tabular}{|l|l|l|c|}
\hline Primary domain & Code & Detailed classification & No.of causes \\
\hline & $\mathrm{C} 1.1$ & In appropriate drug selection & 1 \\
& $\mathrm{C} 1.2$ & Inappropriate dosage selection & 1 \\
Drug/dose selection & $\mathrm{C} 1.4$ & $\begin{array}{l}\text { Pharmacokinetic problems incl. Ageing/ deterioration in organ } \\
\text { function and interactions }\end{array}$ & 9 \\
& $\mathrm{C} 1.7$ & New symptom/indication revealed/presented & 1 \\
& $\mathrm{C} 1.8$ & Manifest side effect, no other cause & 112 \\
\hline \multirow{3}{*}{ Drug use process } & $\mathrm{C} 2.1$ & Inappropriate timing of administration and/or dosing intervals & 14 \\
\hline Information & $\mathrm{C} 2.3$ & Drug over used/over administered & 3 \\
\hline Patient/psychological & $\mathrm{C} 3.1$ & Instructions for use/taking not known & 2 \\
\hline & $\mathrm{C} 4.1$ & Patient forgets to use/take drug & 39 \\
\hline
\end{tabular}

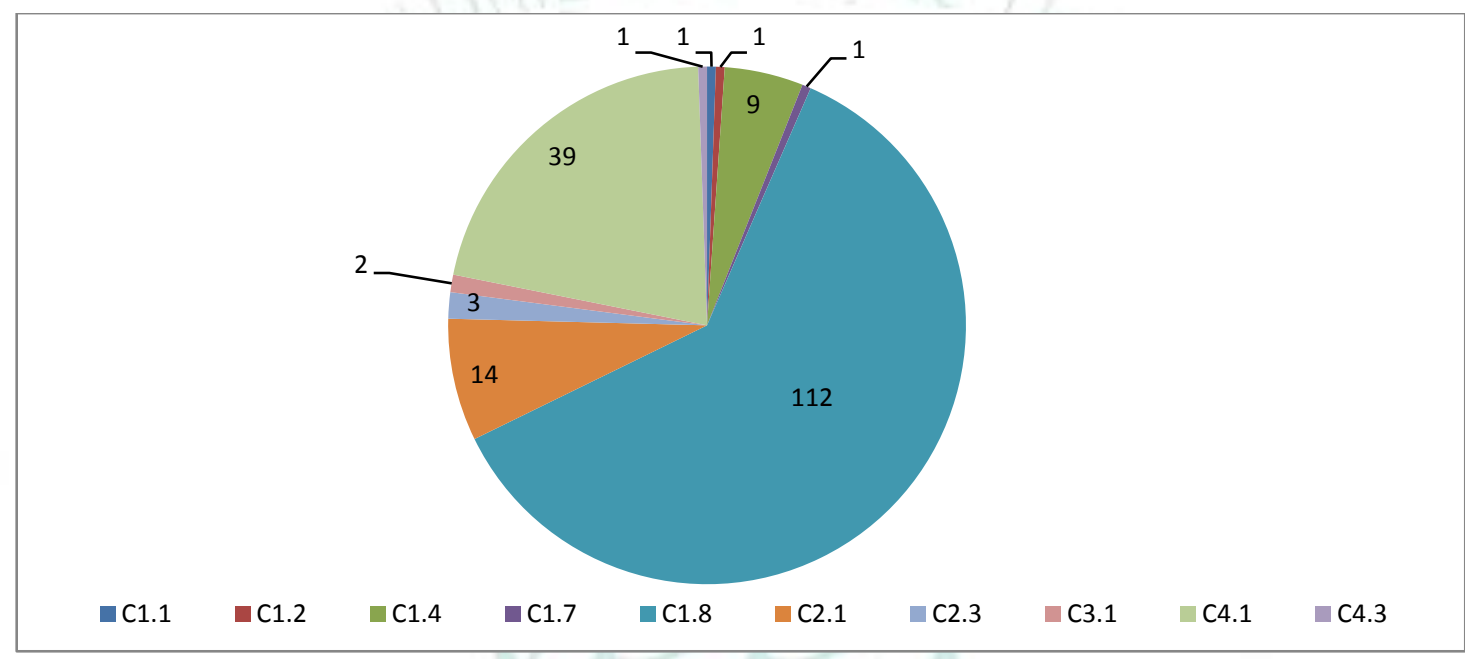

Figure 4: Graph representing distribution of CAUSES as per PCNE

Table 7: List of causes for different problems identified in causes domain and sub domain

\begin{tabular}{|l|l|l|l|l|}
\hline $\begin{array}{l}\text { Primary } \\
\text { domain }\end{array}$ & Code & Detailed classification & Problem & $\begin{array}{l}\text { No. of } \\
\text { Problems }\end{array}$ \\
\hline $\begin{array}{l}\text { Drug/dose } \\
\text { selection }\end{array}$ & $\mathrm{C} 1.4$ & $\begin{array}{l}\text { Pharmacokinetic problems incl. } \\
\text { Ageing/ deterioration in organ } \\
\text { function and interactions }\end{array}$ & $\begin{array}{l}\text { Severe anaemia, blurred vision, finger } \\
\text { paralysis, ear impairment }\end{array}$ & 9 \\
\cline { 2 - 5 } & $\mathrm{C} 1.8$ & $\begin{array}{l}\text { Manifest side effect, no other } \\
\text { cause }\end{array}$ & $\begin{array}{l}\text { Rashes, muscle pain, vomiting, nausea, } \\
\text { headache, cough, abdominal pain, lack of } \\
\text { appetite, lack of sleep, dreams fatigue, } \\
\text { stomach burning, diarrhoea, throat irritation, } \\
\text { anaemia, neutropenia }\end{array}$ & 112 \\
\hline
\end{tabular}

\section{The Interventions:}

As per PCNE we have suggested 330 interventions in 3 main domains with four sub domains. Whereas intervention domain comprises of five main domains consisting of eighteen sub domains.
The 3 main domains where we suggested interventions are $12(3.636 \%)$ interventions at prescriber level, $183(55.45 \%)$ interventions at patient/carer level, and $135(40.90 \%)$ interventions at drug level domain. 
Table 8: Interventions suggested as per PCNE

\begin{tabular}{|c|c|c|c|}
\hline Primary domain & Code & Intervention & $\begin{array}{l}\text { No. of } \\
\text { problems }\end{array}$ \\
\hline No intervention & I0.0 & No intervention & 0 \\
\hline \multirow[t]{5}{*}{ At prescriber level } & I1.1 & Prescriber informed only & 0 \\
\hline & I1.2 & Prescriber asked for information & 0 \\
\hline & I1.3 & Intervention proposed, approved by prescriber & 12 \\
\hline & $\mathrm{I} 1.4$ & Intervention proposed, not approved by prescriber & 0 \\
\hline & I1.5 & Intervention proposed, outcome unknown & 0 \\
\hline \multirow[t]{4}{*}{ At patient/carer level } & $\mathrm{I} 2.1$ & Patient(medication) counselling & 183 \\
\hline & $\mathrm{I} 2.2$ & Written information provided only & 0 \\
\hline & $\mathrm{I} 2.3$ & Patient referred to prescriber & 0 \\
\hline & $\mathrm{I} 2.4$ & Spoken to family member/ care giver & 0 \\
\hline \multirow[t]{6}{*}{ At drug level } & $\mathrm{I} 3.1$ & Drug changed to........... & 0 \\
\hline & $\mathrm{I} 3.2$ & Dosage changed to.................. & 0 \\
\hline & $\mathrm{I} 3.3$ & Formulation changed to................. & 0 \\
\hline & $\mathrm{I} 3.4$ & Instructions for use changed to...... & 12 \\
\hline & $\mathrm{I} 3.5$ & Drug stopped & 0 \\
\hline & I3.6 & New drug started & 123 \\
\hline \multirow{2}{*}{$\begin{array}{l}\text { Other intervention or } \\
\text { activity }\end{array}$} & I4.1 & Other intervention(specify) & 0 \\
\hline & I4.2 & Side effect reported to authorities & 0 \\
\hline
\end{tabular}

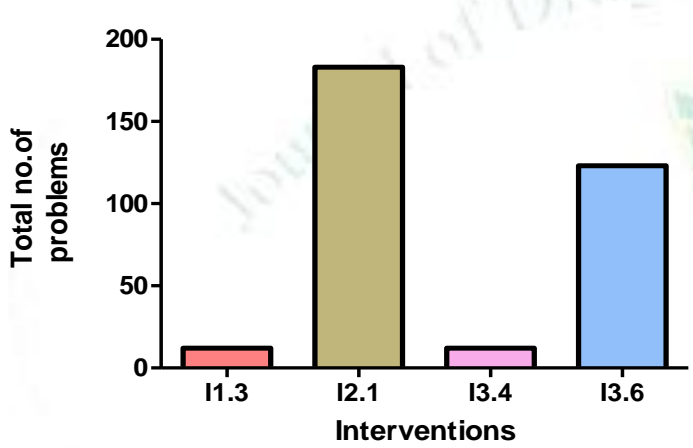

Figure 5: Graph representing interventions suggested as per PCNE in various domains

\section{Outcome of interventions:}

As per PCNE we have assessed the outcomes suggested for 330 interventions. The acceptance rate of interventions suggested was $76.96 \%$. In the outcome domain there are four main domains consisting of seven sub domains whereas in our study 2 outcomes were measured from in two main and two sub domains.

In these domains $254(76.96 \%)$ interventions were solved (interventions were accepted), 76(23.03\%) interventions were partially solved.

Table 9: Outcome of interventions suggested as per PCNE

\begin{tabular}{|c|c|c|c|}
\hline $\begin{array}{l}\text { Primary } \\
\text { domain }\end{array}$ & Code & Outcome of intervention & $\begin{array}{c}\text { No. of } \\
\text { problems }\end{array}$ \\
\hline 0.Not known & $\mathrm{O} 0.0$ & Outcome intervention not known & 0 \\
\hline \multirow[t]{5}{*}{ 1. Solved } & O1.0 & Problem totally solved & 254 \\
\hline & $\mathrm{I} 1.3$ & $\begin{array}{l}\text { Intervention proposed, approved by prescriber ( like potential drug } \\
\text { interactions) }\end{array}$ & 12 \\
\hline & $\mathrm{I} 2.1$ & $\begin{array}{l}\text { Patient(medication) counselling (Rashes, muscle pain, vomiting, } \\
\text { nausea, headache, cough, abdominal pain, lack of appetite, lack of } \\
\text { sleep, dreams fatigue, stomach burning, diarrhoea, throat irritation) }\end{array}$ & 145 \\
\hline & $\mathrm{I} 3.4$ & Instructions for use changed to...... ( like potential drug interactions) & 12 \\
\hline & I3.6 & $\begin{array}{l}\text { New drug started(Rashes, muscle pain, vomiting, nausea, headache, } \\
\text { cough, abdominal pain, lack of appetite, lack of sleep, dreams } \\
\text { fatigue, stomach burning, diarrhoea, throat irritation) }\end{array}$ & 85 \\
\hline \multirow{3}{*}{$\begin{array}{l}\text { 2.Partially } \\
\text { solved }\end{array}$} & $\mathrm{O} 2.0$ & Problem partially solved & 76 \\
\hline & $\mathrm{I} 2.1$ & $\begin{array}{l}\text { Patient(medication) counselling (Neutropenia, anaemia, hyper } \\
\text { pigmentation of skin \& nails, ear impairment, severe anaemia, finger } \\
\text { paralysis, blurred vision) }\end{array}$ & 38 \\
\hline & I3.6 & $\begin{array}{l}\text { New drug started (Neutropenia, anaemia, ear impairment, severe } \\
\text { anaemia, finger paralysis, blurred vision) }\end{array}$ & 38 \\
\hline 3.Not solved & O3.1 & Problem not solved, lack of cooperation of patient & 0 \\
\hline
\end{tabular}




\begin{tabular}{|l|l|l|c|}
\hline & O3.2 & Problem not solved, lack of cooperation of prescriber & 0 \\
\cline { 2 - 4 } & O3.3 & Problem not solved, intervention not effective & 0 \\
\cline { 2 - 4 } & O3.4 & No need or possibility to solve problem & 0 \\
\hline
\end{tabular}

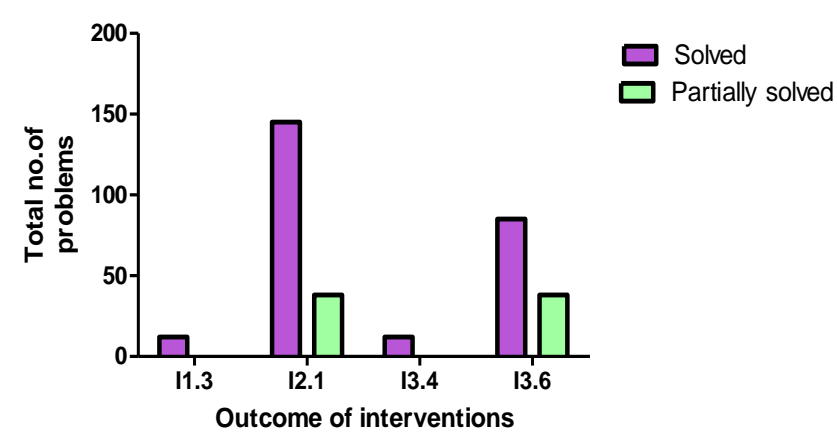

Figure 6: Graph representing outcome of interventions as per $\mathrm{PCNE}$

\section{DISCUSSION}

The study entitled "screening of drug related problems in HIV patients receiving anti retroviral therapy" in the ART department in a tertiary care hospital was conducted for a period of six months (february2016july2016). A Total of 125 patients were enrolled in the study based on inclusion and exclusion criteria.

In our study gender difference was found with males having higher number of ADRs than females which was in contrast with the study done by Lieketseng $\mathrm{J}$ Masenyetse(2015) where females had more number of ADRs than males.

Patients in the age group of 29-38 years experienced more number of adverse drug reactions in the present study which was in contrast with the study done by Srikanth AB et al.(2012) where patients older the ages 38 years experienced significantly higher recurrence of ADRs compared to patients aged 30 years and less. ${ }^{\mathbf{1 0}}$

In the present study co morbid condition like tuberculosis was considered as one of the predisposing factor for ADRs which was supported by the study done by Languluri Reddenna et al.,(2013). ${ }^{\mathbf{1 1}}$

\section{REFERENCES}

1. Patricia van den bemt, Toine Egberts, et al. Drug-related problems: definitions and classification. EJHP practice. 2007 13:62-64.

2. Edwards IR, Aronson JK. Adverse drug reactions: definitions, diagnosis, and management. Lancet 2000; 356:1255-1259.

3. International monitoring of adverse reactions to drugs. Adverse reaction terminology. Uppsala: WHO Collaborating Centre for International Drug Monitoring, 2002.

4. PCNE classification scheme for drug related problems V1.2. Available http://www.pcne.org/upload/files/12_PCNE_classification_V1 .pdf (accessed on 06/07/2016).

5. $\mathrm{PCNE}$ classification scheme for drug related problems V2.04. Available http://www.pcne.org/upload/files/13_PCNE_classification_V2 -04.pdf (accessed on 06/07/2016)

6. $\mathrm{PCNE}$ classification scheme for drug related problems V3.01. Available
Patients taking zidovudine+ lamivudine+ neviraine(ZLN) combination had higher rates of ADRs compared to patients on Tenofovir + Lamivudine + Efavirenz(TLE). It has also been found that patients taking Tenofovir + Lamivudine + Efavirenz(TLE) experienced higher rates of ADRs compared to patients taking Tenofovir + Lamivudine+ Atazanavir/ Ritonavir(TL+Ata/Rit). It supports the previous study done by Languluri Reddenna et al.,(2013) ${ }^{\mathbf{1 2}}$ and which was in contrast with the study done by Ramanjireddy Tatiparthi et al.,(2014). ${ }^{13}$

As per PCNE the main domains which were responsible for problems were the patients with 'adverse reactions', 'drug interactions' and 'drug use problem'. The main ADRs were anaemia, muscle pain, vomiting, nausea, headache, diarrhoea, blurred vision, rashes and the toxic ADRs are ear impairment, severe anaemia, finger paralysis which was similar to the study done by $\mathrm{B}$. Divakar, S. D. Mistry et al.,(2009) ${ }^{\mathbf{1 4}}$. Drug use problem i.e, drug not taken(non adherence) was one of the cause for ADRs which was similar to the study done by Visanou Hansana et al., (1999). ${ }^{15}$

\section{CONCLUSION}

Our study concludes adverse drug reactions with ART are high in problems domain as per PCNE, which can be decreased by identifying DRPs in early stages of drug therapy, prescribing other drugs cautiously in HIV patients. Majority of DRPs can be decreased by improving patient-physician relationships and patientpharmacist relationships.

For better outcomes patient counselling can be considered as a better interventional tool which will improve adherence and decrease DRPs in HIV patients.

Conflicts of Interest: Nil

http://www.pcne.org/upload/files/14_PCNE_classification_V3 -01.pdf (accessed on 06/07/2016)

7. PCNE Classification scheme for Drug-Related Problems V4.00. Available at: http://www.pcne.org/upload/files/15_PCNE_classification_V4 -00.pdf (accessed on 06/07/2016)

8. PCNE Classification scheme for Drug-Related Problems V5.01. Available at: http://www.pcne.org/upload/files/16_PCNE_classification_V5 .01.pdf (accessed on 06/01/2016)

9. Lieketseng J Masenyetse, Samuel OM Manda et al. An assessment of adverse drug reactions among HIV positive patients receiving antiretroviral treatment in South Africa. AIDS Research and Therapy. 2015; 12:6.

10. Srikanth $\mathrm{AB}, \mathrm{Babu} \mathrm{SC}$ et al. Incidence of adverse drug reactions in human immune deficiency virus-positive patients using highly active antiretroviral therapy. J Adv Pharm Technol Res. 2012; 3:62-7. 
11. Languluri Reddenna, Shaik Ayub Basha et al. Highly active antiretroviral therapy: incidence of adverse drug reactions. IJAMSCR. 2013;1(1):25-30.

12. Ramanjireddy Tatiparthi, Yitagesu Mamo et al. Prevalence of ADRs and associated factors of antiretroviral treatment on HIV positive adults at Jush. Indian Journal of Pharmacy Practice. 2014; 7(4).

13. B. Divakar, S. D. Mistry et al. The study of adverse drug reactions (ADRs) in HIV patients taking highly active antiretroviral therapy in art centre, nch, surat, india. IJMPS. 2012; 03(02):9-18.
14. Visanou Hansana, Pattara Sanchaisuriya et al. Adherence to antiretroviral therapy (ART) among people living with HIV (PLHIV): a cross-sectional survey to measure in Lao PDR. BMC Public Health. 2013; 13(617): 1-11.

15. Caroline de Godoi Rezende, Costa Molino et al. Impact of pharmacist interventions on drug-related problems and laboratory markers in outpatients with human immunodeficiency virus infection. Therapeutics and clinical risk management. 2014; 10:631-639. 